\title{
I. SOCIAL, SEXUAL AND PERSONAL IMPLICATIONS OF PARAPLEGIA
}

\author{
Colette Ray, B.A., Ph.D. and Julia West, B.A. \\ Department of Psychology, Brunel University, Uxbridge, Middlesex UB8 ${ }_{3} P H, U . K$.
}

Summary. Paraplegia can lead to social stigmatisation, sexual difficulties, and emotional maladjustment. The specific nature of problems experienced in these areas were investigated in an interview study of 22 male and female paraplegics. These interviews were followed up by a postal questionnaire and both qualitative and quantitative data are presented in this report. Effective counselling can only be offered on the basis of an understanding of problems as they are subjectively experienced, and with an acknowledgement of the wide differences that exist between individuals in the way that they view and react to their situation.

Key words: Paraplegia; Adjustment; Psychology, Spinal Cord Injury.

\section{Introduction}

\section{Social implications}

Physical Disability has been described as a 'stigma', a term which refers to any attribute which marks its possessor as different from others, discredits him or her and disqualifies the person from a full participation in society (Goffman, I963; Katz, I98 I). As part of the process of stigmatisation there is a tendency to 'typify' the whole person on the basis of the attribute in question. Thus, the disabled person will find that his or her social identity has been redefined in terms of the disability (Rubington and Weinberg, I973) and, furthermore, that this redefinition results in some degree of social exclusion and rejection. Attitudes towards the disabled are ambivalent. On the one hand there exists a positive prejudice. People are often protective, helpful and considerate in their behaviour, and rate the disabled in favourable terms (Kleck, I968; Mussen and Barker, 1944). On the other hand, disability can be a source of distress and embarrassment for the able-bodied; people often avoid contact with the disabled and are critical towards them (Kleck, I968; Piliavin et al., I975; Snyder et al., I979; Tringo, 1970). Our self perception depends in part upon the image that we are seen to have in the eyes of others (Mead, 1934) and the disabled person may come to accept the typification imposed or, if they are rejected by others, may introject this evaluation and value their own worth more negatively.

\section{Sexual implications}

The nature and degree of impairment in sexual functioning after injury to the spinal cord will depend upon the level and the completeness of the lesion. With a complete lesion paraplegic men will rarely experience ejaculation, although orgasm can occur with this. Some have referred to this as a 'phantom orgasm', while others argue that orgasm as such is a 
central event and does not depend for its occurrence upon peripheral responses (Geiger, I979). Male paraplegics will generally be able to achieve a reflexogenic erection, but not a psychogenic one and the erection may be difficult to maintain. Less is known about the sexuality of spinal cord injured women than that of men (Thornton, I979). Vaginal lubrication may still occur as a response to stimulation, and orgasm, as in men. A woman's fertility is not affected, although child-bearing and labour will be more difficult; most men, in contrast, will find that their fertility is severely impaired. The act of intercourse itself is complicated by the spinal cord injury, whichever partner is the injured one. There will be limitations in the positions that can be adopted; involuntary spasms may occur and incontinence, or the management of an indwelling catheter, can be a problem also. Little is known of the psychological impact of sexual dysfunctions. Some commentators have suggested that patients are more concerned about these than about any other aspect of their disability (Bloom, 1974; Breslin, I97I; Cole et al., I973), but this may overstate the case. In one study paraplegics rated sex the least of the major functional losses resulting from their injury; 52 per cent thought the loss of the use of their legs the most important, 35 per cent the loss of control over bowel or bladder, and only I 3 per cent the loss of sexual functioning (Hanson and Franklin, 1976). Furthermore, in long term relationships sexual difficulties may be of secondary importance compared with other problems such as loss of fertility (David et al., 1978).

\section{Personal implications}

The difficulty that any particular individual finds in adjusting to the social, sexual and other implications of injury will depend in part upon the personal significance that these have for him or for her. No stress or crisis is uniform in its impact. This will depend upon how the situation is appraised within the framework of the individual's own life style and values (Lazarus, I966). Thus a person whose sense of personal worth is centred upon their appearance or physical prowess might, other things being equal, be more greatly affected by injury than another whose focus in life is intellectual and non-active. The meaning of the injury at a more general level will also be important. For example, if it is seen (unconsciously or otherwise), as some kind of punishment, then feelings of worthlessness may be enhanced (Simon, I97I). If, in contrast, it is associated with an act of bravery it may acquire a positive as well as a negative meaning; Katz and colleagues (I978) found that disabled war veterans had a more positive self image than people who had received their injuries in accidents at work. Disabled people, as a group, do have a poorer adjustment than the able-bodied (Wright, I960). Those with spinal injuries often have emotional problems (Geis, I972; Hohmann, 1966), have higher scores than normal on the Hypochondriasis, Hysteria and Depression scales of the M.M.P.I. (Bourestom and Howard, 1956), and may be more prone to self destructive behaviour and suicide (Hopkins, I97I).

\section{Aims and Method}

The objective of the study to be reported was to describe the problems 
experienced by persons with paraplegia in these three domains:

I. Social, including both initial meetings with others and friendships.

2. Sexual performance and relationships.

3. Personal adjustment.

The subjects were I I male and I I female paraplegics, between the ages of 20 and 40 (see Table I for description). All had acquired their disability through accidental injury except for one man who had had an operation to remove a spinal tumour. They were contacted through a nation-wide organisation for the disabled, from membership lists for London and the surrounding area. The procedure followed to obtain a sample was tirst to select exhaustively female paraplegics who met these age and geographical criteria from the lists, since women are outnumbered by men, and then subsequently to match with them males of a similar age. This procedure resulted in a sample which would not be representative of the total population of paraplegics. However, the aim of this intensive study was

TABLE I

The Sample

\begin{tabular}{|c|c|c|c|c|}
\hline & Mean age & Marital status & & $\begin{array}{l}\text { Mean years } \\
\text { since onset } \\
\text { of disability }\end{array}$ \\
\hline $\begin{array}{l}\text { Female } \\
\mathrm{N}=\text { I I }\end{array}$ & $32 \cdot 0$ & $\begin{array}{l}\text { single } \\
\text { married } \\
\text { divorced/separated }\end{array}$ & $\begin{array}{l}5 \\
2 \\
4\end{array}$ & $9 \cdot 5$ \\
\hline $\begin{array}{c}\text { Male } \\
\mathbf{N}=\text { I I }\end{array}$ & $3 I \cdot 9$ & $\begin{array}{l}\text { single } \\
\text { married } \\
\text { divorced/separated }\end{array}$ & $\begin{array}{l}7^{\star} \\
1 \\
3^{\star}\end{array}$ & $12 \cdot 2$ \\
\hline
\end{tabular}

* I of the divorced men, and 3 of those who were single, were living with their parents.

to explore in detail the nature of the range of responses and not to estimate the incidence of any given response. This made selective sampling rather than random sampling the procedure of choice. All those selected were contacted by post and, if they were willing to take part in the study, they were later interviewed by appointment in their homes. There were five refusals. The interviews themselves were unstructured except in that subjects were asked about their own and other people's experiences in the domains mentioned above, the aim being to elicit from the interviewees those issues which were of most concern to them personally. This unstructured approach was then complemented by a more structured one 'grounded in' the former (Glaser and Strauss, I 968). The interviews were recorded and transcribed and the themes and responses which emerged provided the basis of a questionnaire which was posted to the same sample. Eighteen of the 22 questionnaires mailed were returned; in two cases of non-return the people concerned were in hospital for treatment at the time of distribution. The sample's responses to the questionnaire are reported in the next section, together with related material from the interviews, to 
illustrate and elaborate upon these. The figures quoted are based on the returned questionnaire sample of 18 , while the quotations are taken from the interview transcripts.

\section{Findings}

\section{Meeting others and friendships}

Nine felt that it has become more difficult to meet people since the injury; four that it is the same now as before; and four that it is actually easier now, (Table II). When asked to name the primary source of difficulty, Most ( $n=I I)$ stressed physical and practical problems. In interview, people talked of the trouble they have with travel, stairs, doors, toilets and so forth and this can make going out more trouble than it is worth. Another factor, which is less obvious but was often mentioned, is the difficulty the disabled person has in moving freely within a social gathering. Opportunities for meeting others may be restricted even if meeting places themselves are accessible:

TABLE II

Meeting others

\begin{tabular}{lccc}
\hline & m & f & Total \\
\hline Easier & 2 & 2 & $\dot{4}$ \\
More difficult & 5 & 4 & 9 \\
The same & 3 & I & 4 \\
No response & I & 0 & I \\
\hline
\end{tabular}

'You can't creep in or out and accidentally on purpose run into anybody. You have to move tables and chairs to do that ... You can't sift your friends and think 'I don't like this one, I'll go and try that next group'. You go into a place, you're kind of 'landed' and people have to come and speak to you and nine out of ten times you get the people who bore you'.

In the questionnaire, a few only described a lack of self confidence and other people's ignorance or rudeness as the primary barrier, but these are significant even if not the most important problem and were often cited as such in interview:

'I think to myself, what have I got to offer a person. Not a lot really'.

'Now I find everyone is looking at me, so now I must be strong and determined. Some days I am full of confidence and can go out, but other days I have a hard time going out and end up in tears. I'm afraid I might drop something or something will go wrong and everyone will look at me. Some days I feel sorry for myself ... The feeling of just going out is stronger now (not to go out) than before. I never had people watching me getting out of my car before, and now I do. I just hate to be so conspicuous. I feel like a big, fat bird in this chair all the time'.

Other people often react with pity or with condescension, or treat the disabled person as though they are mute, deaf or retarded. It is not just 
TABLE III

Friends lost as a result of injury

\begin{tabular}{lccc}
\hline & m & f & Total \\
\hline Many & 3 & I & 4 \\
Some & 2 & 3 & 5 \\
None & 5 & 3 & 8 \\
No response & I & 0 & I \\
\hline
\end{tabular}

TABLE IV

Number of friends since injury

\begin{tabular}{lccc}
\hline & m & f & Total \\
\hline More & 4 & 4 & 8 \\
Less & 5 & I & 6 \\
The same & I & 2 & 3 \\
No response & I & 0 & I \\
\hline
\end{tabular}

the disability that has to be contended with but attitudes toward it within society.

The effects of the injury on friendships varied within the sample: nine have lost 'some' or 'many' friends, and six said that they have fewer friends now. On the other hand, eight claimed not to have lost any friends, and eight said that they have more friends now than before the injury (see Tables III and IV). Many found that, while friends initially had difficulty in coping, they learned to overcome this with time. It was a short-lived problem:

'You learn how to cope with the wheelchair and ignore it and because you're not embarrassed by the wheelchair you're not aware of any difference any more. So it's the same with friends too. They forget about the wheelchair and see only you. You are you, and your friends, if they're your friends, will learn to adjust too'.

Other people were less lucky and did lose friends. The latter may have drifted away because they could not cope with the demands they perhaps anticipated, or with their own emotional response to disability. Sometimes, moreover, the disabled person him or herself may have become more withdrawn, both in the physical sense of having their activity restricted and in the psychological sense as a reaction to the trauma of injury. The friends who stayed were particularly valued; they have been the 'real' friends. Similarly, some people said that their friendships since their injury have been deeper and more sincere.

One's circle of friends changes with circumstances and many disabled people will have as friends others who are themselves disabled. Only two of the sample said they have no disabled friends; Is have 'some' or 'a few' and one has mostly disabled friends (Table $\mathrm{V}$ ). Half of the respondents $(n=9)$ go 'often' or 'sometimes' to events or groups specifically for the disabled, but a similar number go 'rarely' or 'never' (Table VI). In interview, attitudes towards such groups were divided. It is easier to talk with others who share the same problem: 


\begin{tabular}{lccc}
\multicolumn{5}{c}{ TABLE V } \\
$\begin{array}{l}\text { Friends } \\
\text { sholves disabled }\end{array}$ \\
\hline & m & f & Total \\
\hline Most & I & 0 & I \\
Some & 5 & 3 & 8 \\
Few & 3 & 4 & 7 \\
None & 2 & 0 & 2 \\
\hline
\end{tabular}

\begin{tabular}{lccc}
\multicolumn{4}{c}{ TABLE VI } \\
$\begin{array}{lccc}\text { Attendance } \\
\text { at } \\
\text { events for the disabled }\end{array}$ \\
\hline & m & f & Total \\
\hline Often & 2 & 0 & 2 \\
Sometimes & 4 & 3 & 7 \\
Rarely & 3 & I & 4 \\
Never & 2 & 3 & 5 \\
\hline
\end{tabular}

'I can talk to other people in wheelchairs a lot easier. We have something in common. It starts off "Where do you come from"? "What kind of car do you drive"? "What kind of hand controls have you got"? And it goes on from there. Other people - you talk about the weather'.

'If they're spinal cord injured, I can relate to them easier. I don't need to explain things to them - they know what you're talking about and you can't talk to 'walkie-talkies' about (those sort of) problems, like catheters and urinal blockages. You can relate to people who are the same'.

However, several voiced reservations about relying too much upon this kind of group. It can be the 'easy way out', allowing people to avoid the challenge of mixing with the able-bodied, and encouraging them to dwell on their disability:

'You shouldn't have to rely upon purely disabled company, you should have both'.

'Most people just don't try to adapt and only participate in wheelchair activities'.

'A lot of paraplegics dwell on their problems and are boring so they mostly go to groups of people who are like themselves and don't go any farther. They stay at that level'.

Some also reacted against the whole notion of organising their social life on the basis of this one attribute and reject an identification with disabled people as a group and with their problems.

'It depends on what sort of people you want to meet, because a lot of people in 
wheelchairs, they try to find other people in wheelchairs to talk to. They stick with their own kind. And I don't want to stick with my own kind because I don't especially like to see myself as disabled'.

\section{Sexual performance and relationships}

For only two was sex described as a 'great problem' but few thought it 'no problem' (Table VII); for most $(n=13)$ it was a 'bit of a problem'. Sixteen felt a need for sex. Most have had some sexual experience since their injury (I6) (all but two of these during the past year), and eight have had sex with more than one partner. Surprisingly, few claimed to have specific problems with position during intercourse $(n=4)$, or spasms $(n=4)$. The most salient problem is the male one of achieving or maintaining an erection $(n=8)$. Five experience orgasm. Sexual feelings, one's partner's pleasure, and the feeling of closeness with the partner were all frequently cited as sources of pleasure during intercourse.

TABLE VII

Sexual implications

\begin{tabular}{lccc}
\hline & m & f & Total \\
\hline A great problem & 2 & 0 & 2 \\
A bit of a problem & 8 & 5 & I3 \\
No problem & I & 2 & 3 \\
\hline
\end{tabular}

From the interviews it seemed that none felt sex to be impossible for the paraplegic but they felt that it is much complicated by the fact of the disability. It takes practice, technique and perseverance to overcome difficulties; it takes also an understanding partner and a sense of humour:

'You have to have time to learn to laugh as well, to have pleasure. It is the sense of humour which helps you to get out of all sorts of different situations which needn't culminate in sexual satisfaction at all. The whole thing sort of collapses in a heap of bodies because of laughter'.

Sex loses its spontaneity and can become an obstacle course. A greater problem, though, than these practical difficulties is the self doubt that people experience about their attractiveness as partners. They know they can perform sexually and can focus upon the kinds of pleasure that they can give and can receive. However, in comparison with other able-bodied men and women, the person with paraplegia may still feel at a relative disadvantage:

'Every woman likes to feel sexually attractive and you don't feel sexually attractive sitting in a wheelchair'.

'Relationships with men change with time anyway, but when you become paralysed your confidence as a woman is very severely hit. It is true that it is less likely that a man would choose you over an able-bodied woman'. 
'... it's hard to break off and try a new girlfriend, because you think, 'God, who will like me like this'?

Doubts about one's attractiveness can then in turn influence performance, producing yet more difficulties:

'It isn't the inner problem really of "can the man perform"? but instead all the inner conflicts he has is what messes him up. Sort of a form of hysteria that spreads until he really can't perform. Little thoughts and worries grow into trees, at least it's what I observed'.

The interviews seemed to elicit more conflict and difficulties than the questionnaire and, indeed, several interviewees worried that they sometimes are less than candid about their feelings in this area, both to themselves and to others:

'There's this big macho image, so they never talk about it. There's no way a guy is going to tell you he can't do it'.

'Many women still play the game answering stereotype questions with stereotype answers. It is emotional for all of us'.

Sex was seen by almost all as having a status similar to, or lesser than, other difficulties experienced since injury $(n=9$ and 6 respectively, see Table VIII). Only two saw it as a greater worry than others. Eight of the sample would have liked some special support to help them to cope with sexual aspects of the disability but as many as six would not themselves have wanted this kind of intervention. There was somewhat greater

TABLE VIII

Sex in relation to other problems

\begin{tabular}{lccc}
\hline & m & f & Total \\
\hline A greater worry than most & 2 & 0 & 2 \\
Less of a worry than most & 5 & I & 6 \\
The same as most & 4 & 5 & 9 \\
Cannot say & 0 & I & I \\
\hline
\end{tabular}

TABLE IX

Desire for special support or counselling

\begin{tabular}{lccccccr}
\hline & \multicolumn{3}{c}{$\begin{array}{c}\text { Sexual } \\
\text { problems }\end{array}$} & \multicolumn{4}{c}{$\begin{array}{c}\text { General } \\
\text { emotional } \\
\text { problems }\end{array}$} \\
\hline & m & f & Total & m & f & Total \\
\hline Yes & 4 & 4 & 8 & 7 & 4 & I I \\
No & 4 & 2 & 6 & 3 & 2 & 5 \\
Do not know & 3 & 0 & 3 & I & 0 & I \\
Already provided & 0 & I & I & 0 & I & I \\
\hline
\end{tabular}


TABLE X

Feelings about self

\begin{tabular}{lccc}
\hline & m & f & Total \\
\hline More positive & 4 & 6 & IO \\
More negative & 2 & I & 3 \\
No change & 4 & 0 & 4 \\
No response & I & 0 & I \\
\hline
\end{tabular}

enthusiasm for the provision of special support when this question was phrased more generally, in terms of general psychological aspects of disability, with 22 saying that they would have liked this and five rejecting the option (see Table IX).

\section{Personal adjustment}

Many of the sample experience depression from time to time ( $N=$ I I). One, in interview, said that he has attempted to commit suicide, and several admitted to using drink as a means of alleviating depression. One problem is frustration at one's own slowness and clumsiness or complete inability to do ordinary things, and frustration at other people for their lack of understanding. Then, too, self-image is affected. The disabled person can feel set apart from others, both in his or her own eyes and in those of others:

'I tend to go around looking at the ground all the time. I hate people looking at me. I know I'm an object and I'm different'.

On the other hand only a minority, when responding to the questionnaire, felt that their feelings about themselves have changed, overall, for the worse $(n=3)$. Four reported no change, and more than half the respondents claimed that their feelings have become more positive since the injury (see Table $\mathrm{X}$ ). In interview, people said that they are now more confident, more patient and stronger. They have been forced to face up to challenges and have come through these. They felt that they know now what they are capable of and that their understanding of themselves and of life is greater:

'I really have been lucky in a whole lot of advantages that this has given me. I'm now happier because it's caused me to go another direction in my life that's turned out to be better - encouraged my individuality and forced me to try new things. I've been able to build up a 'self-love' and appreciate what I'm doing'.

'Basically it has made me more confident, more sure of myself inside myself - I've gotten down to the very base of things'.

'Sometimes it's good to have something to bring (feelings) to the surface. The more aware you are of your own emotions the more aware you are as a person, even though it is a traumatic way to go about it. But if you cope with it (the accident) it's a plus rather than a minus'. 
Through suffering and through greater self awareness, you can become less selfish and more caring. You learn compassion:

'It's turned me from being very selfish, very self-centred. It's turned me around a great deal that way. I see that as something good coming out of it all'.

'I think I'm more caring now. I couldn't do anything malicious to anybody now. I wouldn't want to now'.

'You understand people a lot more, you try and see things through other people's eyes. You find you try to put yourself in their place all the time'.

Through suffering, also, you can come to appreciate things more keenly-not only what you had before and now are missing, but also the everyday things that can still be experienced. Little things and life itself can become that more precious:

'Before I was never in (at home). I was going through life with my eyes shut. I wasn't taking any notice. I mean I didn't stay up and watch the dawn come out and listen to the birds and look at the sky and just look at a flower and think how marvellous, or even look at your own body. That's another thing-it's amazing how you take everything for granted when you've got it. It's not until you lose it that you realise how absolutely amazing that thing was'.

'I've become much more mature. I've become much more aware of the quality of life and aware that life can end at any time and for any reason'.

'I try now to be more observant. I find myself now deliberately trying to look, to observe nature'.

\section{Conclusions}

In summary, for many people, social activities are inevitably restricted as a consequence of disability. Yet, there are some who find no difference, or even profit from the disability in the sense of now meeting more people than they did before the injury. People vary also in their experience of the effect that paraplegia has had upon their close friendships. Again, some had, overall, lost friends while others had gained. Disabled groups are seen by many as an important source of support, a way of meeting others who can understand your situation and share your experiences. Many, however, see these groups as a threat, in that they can encourage overidentification with the disability. People's experiences and attitudes with respect to the social implications of paraplegia are thus very different. A stereotyped image of the social impact of paraplegia is no more appropriate than a stereotype of the disabled themselves.

Most of those who took part in the study have had some sexual problems after injury though few saw these as of greater magnitude than their other worries. Technical aspects of sexual performance and interference with pleasure are only one aspect. The implications for one's self image as a sexual person seem to be just as undermining, and any support provided for the newly disabled should deal with the doubts they will have about their attractiveness and adequacy as a sexual partner and not just with techniques and practicalities. Under half of the sample, indeed, felt that they would have welcomed support in this area but a greater number 
favoured the idea of more general psychological support. This suggests that sexual counselling might be most effectively offered in the context of general counselling rather than in isolation. The issue of counselling, and the ways of coping it might promote, is one that will be taken up in another paper.

Disability is a threat to the person at a number of levels but it is a threat that many are able to overcome. Depression and frustration may occur from time to time but the person who has survived the initial trauma and tackled the problems that arise afterward may find a new sense of self confidence and fulfilment as a result of the experience. The goal of adjustment, therefore, should not be merely to conserve as much as possible of what one had before, but to accommodate to the new situation, to compensate positively for what has been lost by exploring new interests, and to make this an opportunity for personal growth rather than an occasion for despair.

\section{Acknowledgement}

This project was initiated and funded by the society for the Sexual and Personal Relationships of the Disabled.

\section{RÉSUMÉ}

La paraplégie peut mener à une stigmatisation sociale, à des difficultés sexuelles et à un defaut d'adaptation émotionnelle. La nature spécifique des problèmes éprouvés dans ces domaines a été examinée dans une étude-interview de 22 paraplégiques mâles et femelles. Ces interviews ont été suivis d'un questionnaire postal et l'on présente des dennées tant qualitatives que quantitatives dans ce rapport. Des conseils effectifs ne peuvent être offerts que sur'la base d'une comprehension des problèmes tels qu'on les éprouve subjectivement, et si l'on reconnaît les différences importantes qui existent entre les individus quant à la façon dont ils regardent et réagissent à leur situation.

\section{ZUSAMMENFASSUNG}

Die Paraplegie kann zu sozialer Stigmatisierung, geschlechtlichen Schwierigkeiten und mangelnder emotionaler Anpassung führen. Die spezifische Art der auf diesen Gebieten erfehrenen Probleme ist in einem Interview-Studium von 22 männlichen und weiblichen Paraplegischen untersucht worden. Diesen Interviews zufolge sind Postfragebögen ausgesandt worden, und qualitative wie auch quantitative Angaben werden in diesem Bericht dargestellt. Eine wirkungsvolle Beratung kann nur auf der Grundlage von einem Verständnis der Probleme, wie man sie subjektiv erfährt, angeboten werden, und zwar mit einer Anerkennung der breiten Unterschiede, die zwischen Einzelwesen existieren, was die Weise, worauf sie ihre Lage betrachten und dazu reagieren, betrifft.

\section{REFERENCES}

BLoom, D. S. (1974). Sexual aspects of physical disability. American Archives of Rehabilitation Therapy, 22, 32-39.

Bourestom, N. C. \& Howard, M. T. (1965). Personality characteristics of three disability groups. Archives of Physical Medicine, 40, 626-632.

BREsLin, C. (I97I). In Ward at Bronx V.A: Talking about the unspeakable. New York Magazine, 43-52.

Cole, T. M., Chilgreen, R. \& Rosenberg, P. (I973). New programme of sex education and counselling for spinal cord injured adults and health care professionals. Paraplegia, II, I I I-I 24 .

David, A., GuR, S. \& Rozin, R. (I978). Survival in marriage in the paraplegic couple. Paraplegia, I5, I98-20I. 
Geiger, R. C. (1979). Neurophysiology of sexual response in spinal cord injury. Sexuality and Disability, 2, 237-266.

GeIs, H. (1972). The problem of personal worth in the physically disabled patient. Rehabilitation Literature, 33, 34-39.

GLASER R. G. \& STRAuss, A. L. (I968). The discovery of grounded theory: strategics for qualitative research. Weidenfeld and Nicolson, London.

Goffman, E. (1963). Stigma. Prentice Hall, New Jersey.

Hanson, R. W. \& FrankLIN, M. R. (I976). Sexual loss in relation to other functional losses for spinal cord injured males. Archives of Physical Medicine and Rehabilitation, 57, 29I-293.

HohmanN, G. W. (1966). Some effects of spinal cord lesions on experienced emotional feelings. Psychophysiology, 3, I 43-1 56.

Hopkins, M. (I97I). Patterns of self destruction among the orthopaedically disabled. Rehabilitation Research and Practice Review, 3, 5-16.

Katz, S., ShURKa, E. \& Florian, V. (I 978). The relationship between physical disability, social perceptions and psychological stress. Scandinavian fournal of Rehabilitation Medicine, 10, I09-I I 3 .

Katz, K. (I98I). Stigma: a social psychological analysis. Lawrence Gilbaum, Hillsdale, New Jersey.

KLECK, R. (1968). Physical stigma and non verbal cues emitted in face to face interaction. Human Relations, 21, 19-28.

Lazarus, R. S. (I966). Psychological stress and the coping process. McGraw Hill, New York.

Mead, G. H. (1934). Mind, Self and Society. University of Chicago Press, Chicago.

Mussen, P. H. \& BARKer, R. G. (1944). Attitudes toward cripples. fournal of Abnormal and Social Psychology, 39, 35I-355.

Piliavin, I. M., Piliavin, J. A. \& Rodin, J. (1975). Costs, diffusion and the stigmatised victim. Fournal of Personality and Social Psychology, 32, 429-438.

Rubington, E. \& Weinberg, M. S. (Eds). (1973). Deviance: the interactionist perspective. MacMillan, New York.

Simon, J. K. (I97I). Emotional aspects of physical disability. The American fournal of Occupational Therapy, 25, 402-410.

Snyder, M. L., Kleck, R. E., Strenta, A. \& Mentzer, S. J. (i979). Avoidance of the handicapped: an attributional analysis. Fournal of Personality and Social Psychology, 37, 2297-2306.

ThoRnton, C. E. (1979). Sexuality counselling of women with spinal cord injuries. Sexuality and Disability, 4, 267-277.

TRINGO, J. L. (I970). The hierarchy of preference toward disability groups. Fournal of Special Education, 4, 295-306.

Wright, B. (1960). Physical disability: a psychological approach. Harper and Row, New York. 